\title{
How Do We Love? Romantic Love Style in Men Is Related to Lower Testosterone Levels
}

\author{
J. BABKOVÁ DURDIAKOVÁ ${ }^{1}$, P. CELEC ${ }^{2,3}$, I. KOBOROVÁ ${ }^{2}$, T. SEDLÁČKOVÁ ${ }^{2,4}$, \\ G. MINÁRIK ${ }^{2,4}$, D. OSTATNÍKOVÁ ${ }^{1}$ \\ ${ }^{1}$ Institute of Physiology, Faculty of Medicine, Comenius University, Bratislava, Slovakia, ${ }^{2}$ Institute \\ of Molecular Biomedicine, Faculty of Medicine, Comenius University, Bratislava, Slovakia, \\ ${ }^{3}$ Institute of Pathophysiology, Faculty of Medicine, Comenius University, Bratislava, Slovakia, \\ ${ }^{4}$ Department of Molecular Biology, Faculty of Natural Sciences, Comenius University, Bratislava, \\ Slovakia
}

Received October 25, 2016

Accepted January 12, 2017

On-line April 12, 2017

\begin{abstract}
Summary
Testosterone has been widely investigated in associations with many aspects of social interactions, emotions and behavior. No research has been conducted on its contribution to the variability of love styles in human. The aim of this paper was to uncover the possible relationship between not only the actual plasma testosterone levels, but also the prenatal testosterone level (expressed as 2D:4D ratio) and the sensitivity of androgen receptor and love typology in young healthy men. There are six love styles which are primary including Eros (passionate romantic love), Ludus (playful) and Storge (friendly) and secondary love consisting of Mania (obsessive), Pragma (practical realistic) and Agape (altruistic). Our results pointed out that low testosterone concentrations are associated with higher score for Eros, Ludus, Pragma, Mania love style. No significant association was proved for other tested parameters of androgenicity (2D:4D, sensitivity of androgen receptor) and love style after correction was applied. Different attitudes and behavior in relationships do have a biological foundation related to endogenous testosterone levels in plasma. Future studies should address questions about the family and social background of participants to differentiate here between moral rules or/and social-conventional rules.
\end{abstract}

\section{Key words}

Testosterone • 2D:4D • Love styles • Androgen receptor

\author{
Corresponding author \\ J. Babková Durdiaková, Institute of Physiology, Comenius \\ University, Sasinkova 2, 81372 Bratislava, Slovakia. E-mail: \\ durdiakova.jaroslava@gmail.com
}

\section{Introduction}

Love is one of the most intense feelings we experience during our lives. There is no wonder it has been source of inspiration ever since the beginning of a mankind. It has become part of the art, literature, music and film. Despite love cannot be considered a scientific concept, it draws a lot of attention of scientific community trying to uncover biological, neurological and endocrine aspects hidden behind a depth and beauty of love (De Boer et al. 2012, Francesco and Cervone 2014, Gompel and Prud'homme 2009, Zeki 2007).

Literature distinguished several varieties of romantic love (Hendrick et al. 1998, Cho and Cross 1995). There are six love styles which are primary including Eros, Ludus and Storge and secondary love consisting of Mania, Pragma and Agape (Lee 1998). Eros is literally the love of beauty. It reflects highly sensual, intense, passionate style of love. Erotic lovers choose their lovers by intuition or chemistry. Emotional attraction is followed by commitment to the loved one (Lee 1973). Ludus is characterized as a playful love. This style is used by those who see love as a game and focus 
on having fun. Ludic lovers are rarely emotionally involved and keen on sharing intimacy and thoughts with partner (Lee 1973). Storge refers to love in which relationship developed slowly from friendship (Lee 1973). Those who practice this love have a strong commitment towards the relationship. Pragma love is a practical and realistic style. Love is perceive in a "business-like" manner with partners sharing common goals and conscious compatibility (Lee 1988). Manic love is characterized results in an obsessive, intense, full feeling and possessive kind of love. Those people who belong to this love style have a strong need to be loved (Lee 1988). Agape is altruistic type of love based on commitment, unconditional and selfless feelings. Lovers of this sort are willing to sacrifice anything for their partner increasing the quality of love with the need for mutual helping (Lee 1988).

Testosterone plays a key role in regulation and facilitating of mating effort by promoting male-male competition and also mate-seeking behavior (Archer 2006). Literature provides lots of evidence showing higher testosterone levels in unmarried, uncommitted single men versus committed/married ones (Kuzawa et al. 2009, McIntyre et al. 2006). Current knowledge does not directly speak to the issue of causality. There are reasons to expect that relationship status affects testosterone levels. This assumption is supported by the study indicating that to fall in love provokes transient hormonal changes (Marazziti and Canale 2004). On the other hand it was suggested that low testosterone promotes the relationship orientation comparing to high concentrations that keep men in some sense "not taken off market" facilitating their libido, jealousy and mating effort (Alvergne et al. 2009, Archer 2006, Burnham et al. 2003). Consistent gender differences were pointed out in love style between males and females (Worobey 2001). Women tend to be more pragmatic, manic and also practice love based on friendship comparing to men who are more ludic lovers. Some inconsistency was showed in romantic love style and altruistic selfless love. Due to observed sex differences it can be hypothesized that androgens, specifically testosterone, may be responsible for modulating of behavior in intimate personal relationship.

It has been proposed that the ratio of the second to fourth digits (2D:4D) may be a proxy of prenatal androgen exposure, such that low 2D:4D ratio is associated with high prenatal androgen exposure (Beaton et al. 2011, Manning and Robinson 2003). Possible relationships between early androgens exposure and human behavior motivated digit ratio studies analyzing human behavior providing the novel evidence for the organizational effects of hormones on human social interactions (Roney and Maestripieri 2004). For instance, the level of prenatal testosterone indicated by digit ratio was shown to affect the level of jealousy, which are different for men and women (Park et al. 2008) and also the number of sexual partners in heterosexual men (Roney and Maestripieri 2004).

Genetic variability in androgen receptor seems to be another interesting parameter to analyze in order to understand testosterone effect on brain organization. In the range of normal variation, low number of CAG repeats in genes encoding androgen receptor cause higher transactivation activity of receptor and, thus, higher sensitivity to androgens (Greenland et al. 2004). Previously published paper pointed out that variation in CAG repeat length of the androgen receptor gene predicts variables associated with intrasexual competitiveness in human males (Simmons and Roney 2011) but there is still lack of information on how androgen receptor as a major modifier of androgen activity affects social behavior in romantic relationships.

Despite great interest in testosterone in social interactions, emotions and behavior, no research has investigated its contribution to the variability of love styles in human. The aim of this paper was to uncover the possible relationship between parameters of androgenicity (plasma testosterone levels, prenatal androgen priming indicated by 2D:4D ratio on dominant hand and sensitivity of androgen receptor reflected by number of $\mathrm{CAG}$ repeats in gene for $\mathrm{AR}$ ) and love typology in young healthy men.

\section{Methods}

\section{Subjects}

Participants recruited for this study were university students between 19 and 21 years, all of them right handed and apparently healthy $(\mathrm{N}=65)$. The participants signed an informed consent. All procedures were conducted in accordance with the Declaration of Helsinki. The study was approved by the Ethics Committee of the Institute of Molecular Biomedicine, Comenius University. 


\section{Love style examination}

Paper-pencil questionnaire was used to measure attitudes toward love (Lasswell and Lasswell 1976). The questionnaire combines attitudes toward one's current/recent/hypothetical partner with attitudes about love in general. The scale is broken into 6 subscales that each represents a different love style: EROS (romantic passionate love), LUDUS (game-playing love), STORGE (friendship love), PRAGMA (practical love), MANIA (possessive, dependent love), AGAPE (altruistic selfless love). Participants respond to each item using true or false answers in a categorical nature. Percentage of true answers were calculated and used in correlation with biological parameters. Participants are instructed to answer questions with their current partner in mind. However, the instructions state that if the respondent does not currently have a partner, he or she should answer with their most recent partner in mind. However, if the respondents have never been in love, the instructions state that they should provide whatever answer they believe would be true. Questionnaire was translated into Slovak language.

\section{Testosterone concentration measurement in plasma}

Blood samples were drawn from the cubital vein into sterile Blood Collection Tubes (EDTA) (Sarstedt, Nümbrecht, Germany) immediately after questionnaires administration. Blood samples were centrifuged for $10 \mathrm{~min}$ at $2000 \mathrm{x} \mathrm{g}$, and plasma was stored at $-20^{\circ} \mathrm{C}$. Samples were stored at $-20^{\circ} \mathrm{C}$. On the day of testing, frozen samples were brought to room temperature and pipetted into testing plate without any centrifugation of other further processing. Plasma testosterone was measured using a commercially available ELISA kits (DRG Diagnostics, Marburg, Germany). Mean intraassay and inter-assay coefficients of variation are $3.1 \%$ and $8.5 \%$, respectively.

\section{Genetic analysis of androgen receptor}

Genomic DNA from saliva was extracted using the silica membrane based kit (Qiagen, Hilden, Germany) following the manufacturer's instructions (QIAamp DNA Blood Mini Kit Handbook 04/2010) according to DNA purification protocol for blood/body fluids. The (CAG)n repeat polymorphism in exon 1 of the androgen receptor gene was amplified using PCR in $20 \mu \mathrm{l}$ reaction volume with $250 \mathrm{nmol} / \mathrm{l}$ primers: forward: 5' GCGCGAAGT
GATCCAGAAC 3' tagged with 6-carboxyfluorescein and reverse: 5' CTCATCCAGGACCAGGTAGC 3', $1 \times$ Taq buffer (Fermentas, Vilnius, Lithuania) and $1 \mathrm{U}$ of Taq DNA polymerase (Fermentas, Vilnius, Lithuania). The following PCR program was used: initial denaturation step at $94^{\circ} \mathrm{C}$ for $4 \mathrm{~min}$, followed by 35 cycles each consisting of denaturation at $94{ }^{\circ} \mathrm{C}$ for $45 \mathrm{~s}$, annealing at $59.5^{\circ} \mathrm{C}$ for $45 \mathrm{~s}$ and polymerization at $72{ }^{\circ} \mathrm{C}$ for $45 \mathrm{~s}$. The length of the final fragment was $181 \mathrm{bp}$. The number of repeats was analyzed by capillary electrophoresis.

\section{D:4D digit ratio}

Probands provided both of their hands to make a digital scan of ventral surface. The lengths of second and fourth digit were measured twice and ratio was calculated using AutoMetric. Values from right hands (dominant) are present and used for analyses.

\section{Statistical analyses}

The strength of the linear relationship between variables was tested Pearson's correlation analysis. P-values less than 0.05 were considered significant. Multivariate analysis-Test of between-subjects effect was used to show statistically significant effect of independent variables (plasma testosterone levels, mean CAG in AR, right 2D:4D - dominant hand) on the dependent variable (love styles).

\section{Results}

Plasma testosterone level in young men negatively correlated with romantic loving style $(\mathrm{r}=-0.28$, $\mathrm{p}=0.03)$, and selfless altruistic love $(\mathrm{r}=-0.28, \mathrm{p}=0.03)$ (Fig. 1). Lower prenatal testosterone exposure indicated by higher $2 \mathrm{D}: 4 \mathrm{D}$ on right hand enhanced romantic love attitude $(\mathrm{r}=0.26, \mathrm{p}=0.04)$ and also game-playing love style ( $\mathrm{r}=0.26, \mathrm{p}=0.04$ ) (Fig. 2). Number of $\mathrm{CAG}$ repeats representing the sensitivity of androgen receptor did not correlate significantly with any of love styles (Fig. 3).

The corrected model test confirmed that the model as a whole significantly accounts for the variance in the dependent variable (EROS - romantic love). Multivariate model using test of between subjects effects proved that the variability in romantic love behavior can be explained by the variability in plasma testosterone levels $(\mathrm{F}=8.19, \mathrm{p}=0.006)$. 


$$
r=-0.28, p=0.03
$$

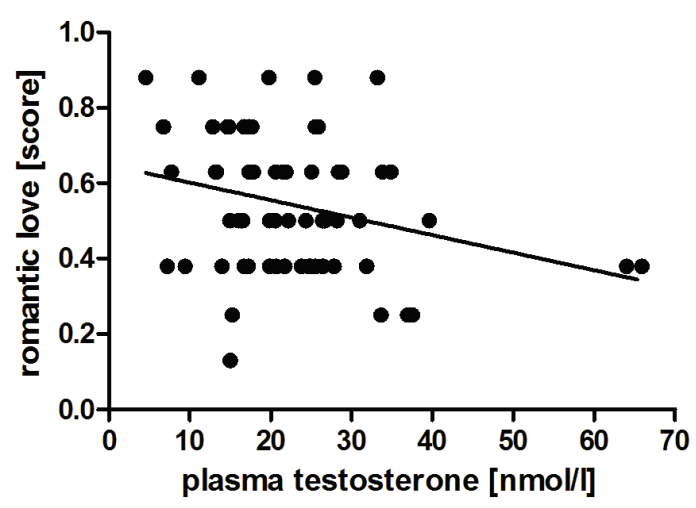

$r=-0.13, p=0.33$

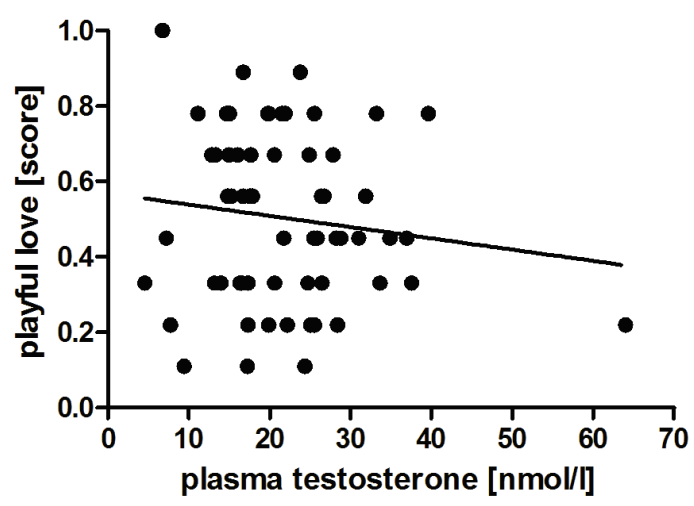

$r=-0.05, p=0.69$

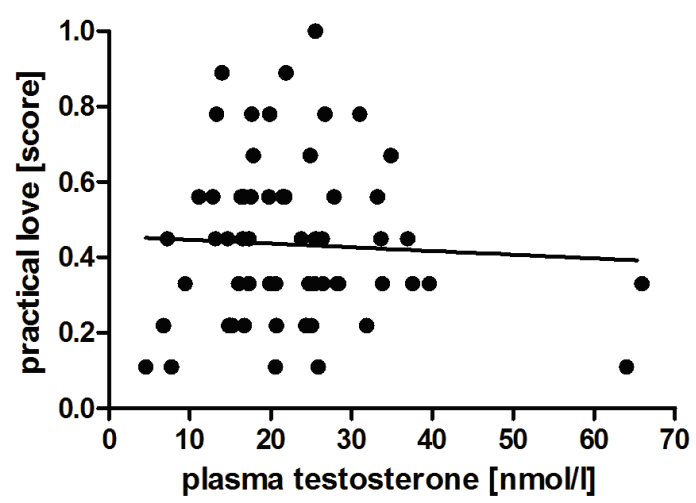

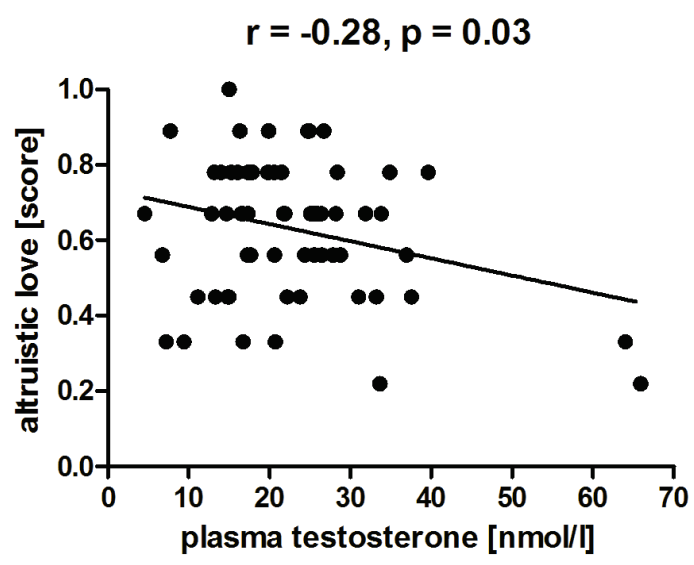
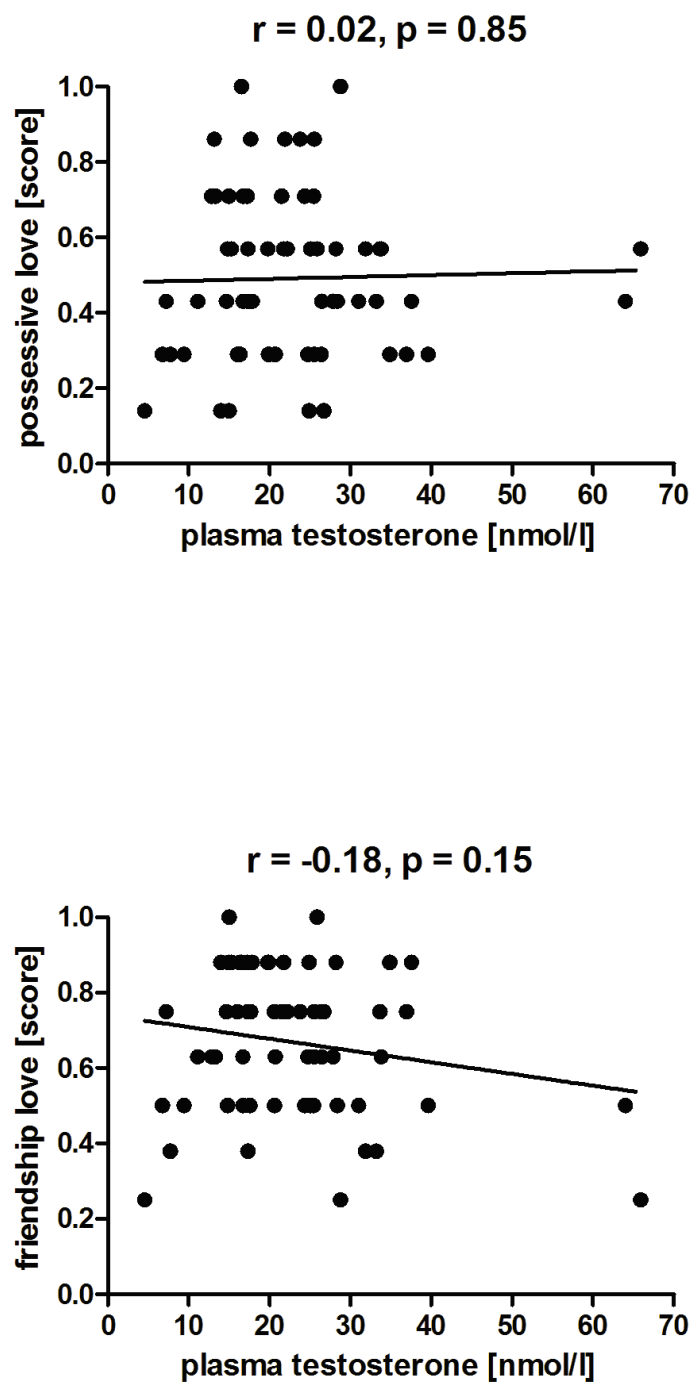

Fig. 1. Correlation analyses between plasma testosterone levels and love styles. 

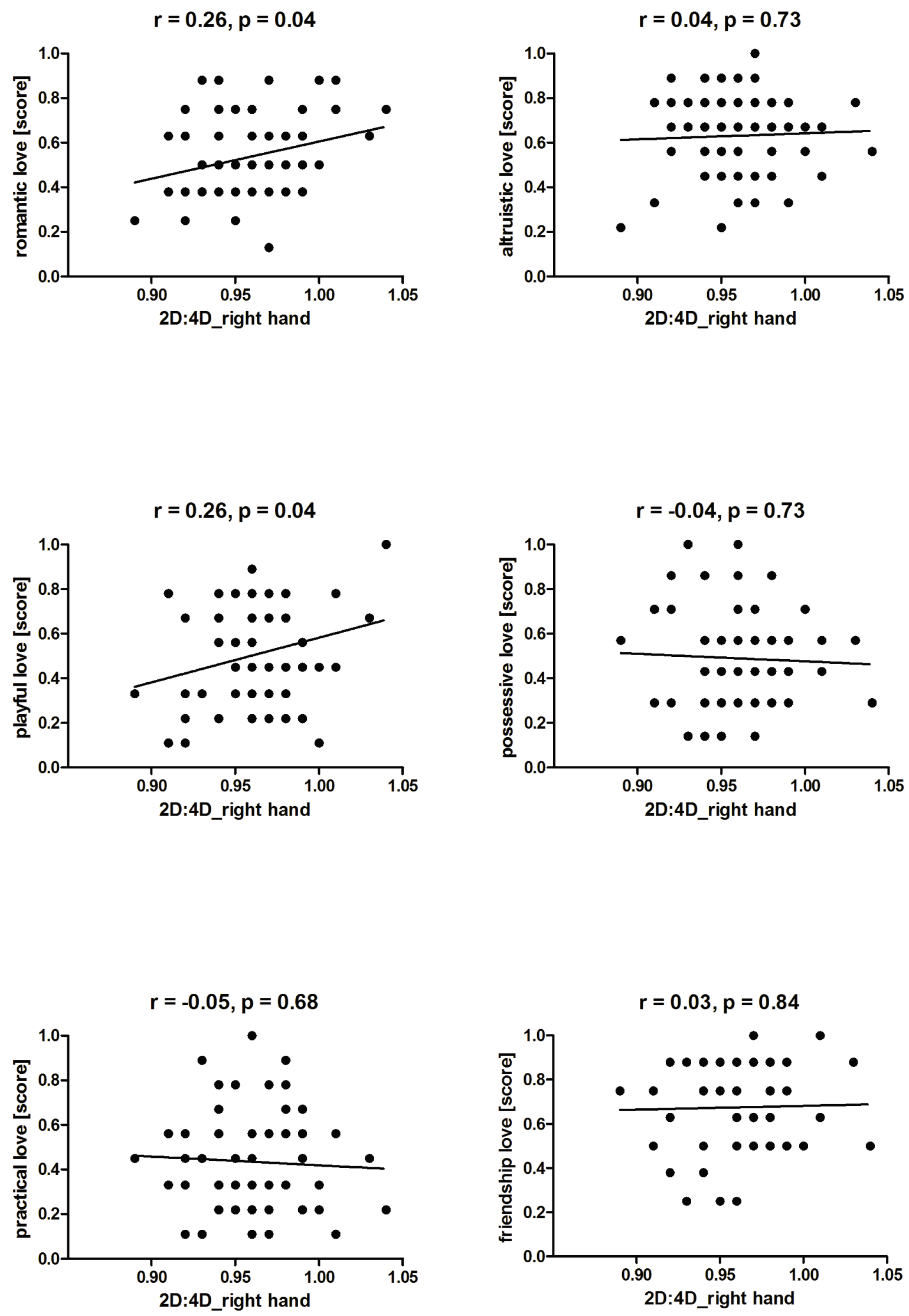

Fig. 2. Correlation analyses between prenatal testosterone exposure indicated by $2 D: 4 D$ ratio and love styles. 

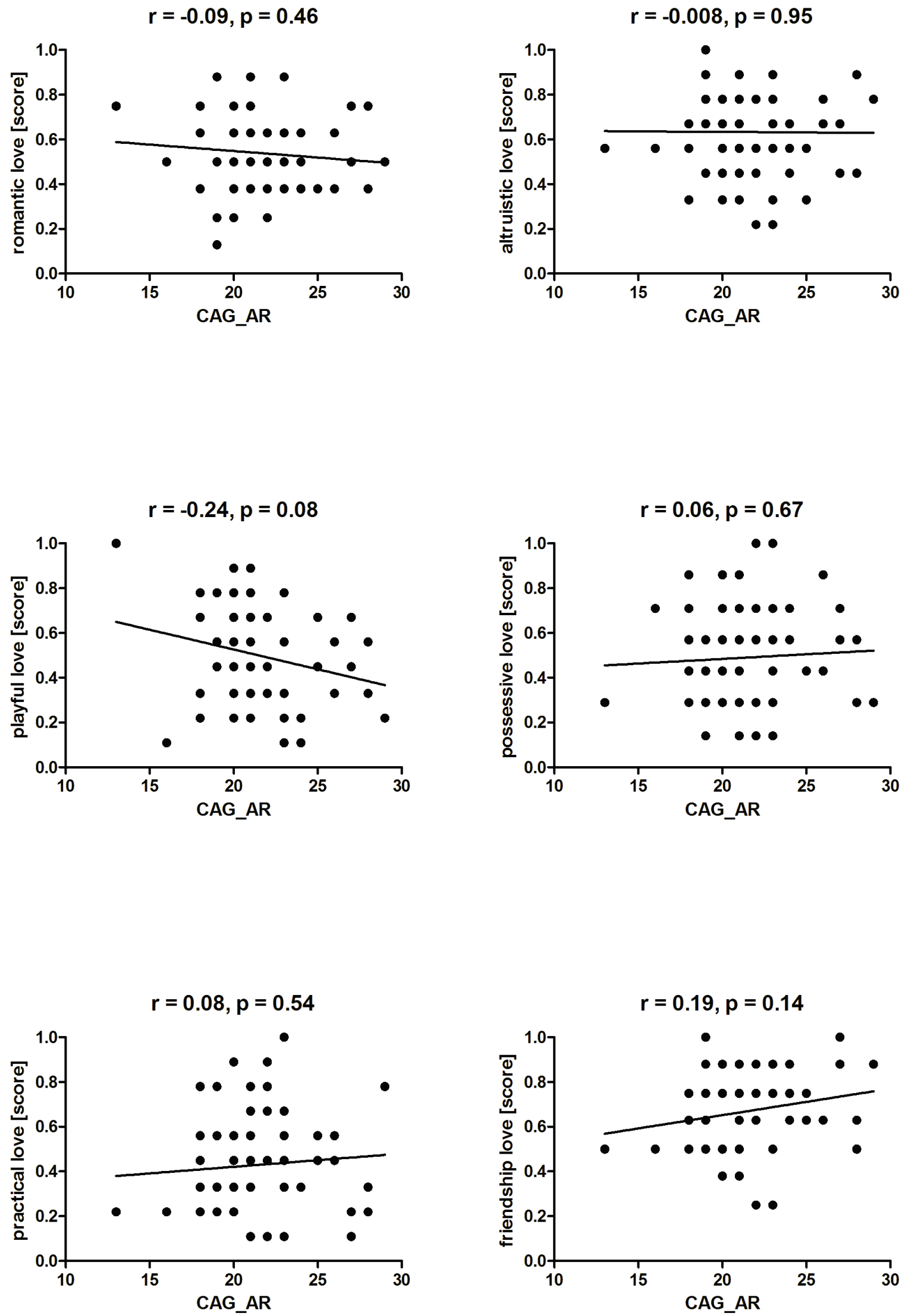

Fig. 3. Correlation between number of CAG triplets and 6 love styles. 


\section{Discussion}

Previous research established testosterone as a social hormone. It suggests that testosterone is involved in modulation of various aspects of behavior; sexual, social interactions and emotions being no exception. We hypothesized that circulating concentrations of testosterone in plasma, prenatal testosterone exposure reflected by 2D:4D or the sensitivity of androgen receptor in young men might be one of the biological correlates responsible for differences of love concepts among individuals.

Our results indicate that higher concentrations of testosterone in young healthy men suppress their tendency to practice EROS style described as a passionate love with deep intimacy and commitment reflecting secure attachment style. Our finding support previously pointed out association between testosterone and relationship/commitment orientation. This interpretation indicates that lower testosterone concentrations incline to get into the relationship and create long lasting and stable bonding sharing the intimacy (Burnham et al. 2003, Van Anders and Watson 2007). Higher testosterone is thought to be associated with increased mating effort, attracting sexual partners, but not compatible with a long-term relationships and romantic attachment. Generally, men and women in satisfying and committed relationships are typically found to have lower testosterone levels (Edelstein et al. 2014). However, to date, there is little evidence for causality between testosterone levels and romantic behavior. The opposing view highlights that relationship status possibly lead to differences in testosterone levels. Certain male relationships, such as long term affiliative bonds or marriage, can be a predictor variable associated with lower testosterone levels (Burnham et al. 2003). Interestingly, results showed that levels of testosterone of single men or men in new relationships did not differ, but both had significantly higher levels than men in longterm relationships (Farrelly et al. 2015). These findings imply that lower testosterone in paired (romantically involved) might be a facultative adjustment in response to lower demands for mating effort and their lower internal motivation to seek new potential mates (McIntyre et al. 2006) .

Alternatively, long-term satisfying relationships may lead to declines in testosterone (Edelstein et al. 2014). Given the correlational nature of our study, we cannot determine the direction of causality between testosterone and ideas about love. There are reasons to expect that testosterone may be causally related to relationship satisfaction. In other words, the quality of relationship we are in affects testosterone concentrations and also our ideas about love. One of the limitations in our study is that we have not investigated current relationship status or/and the quality of partnership so this can be a direction for further study.

In the present study, we also showed the negative effect of plasma testosterone (T) levels on AGAPE altruistic love style. This is in agreement with other correlational studies suggesting that generally high $\mathrm{T}$ appear to be more aggressive and less prosocial (Alvergne et al. 2009). Salivary testosterone in humans have found that high $\mathrm{T}$ men are more likely to divorce more often, spend less time with their children, engage in competition of all types, have more sexual partners proving that high $\mathrm{T}$ men behave differently than other men (Alvergne et al. 2009). Also administration study with artificially raised $\mathrm{T}$ proved that $\mathrm{T}$ appears to play a role in inducing men to change from being selfless to being selfish (Zak et al. 2009). Males with lower testosterone levels perhaps exhibit lower intensity of male mating competition, reduced interest in mate seeking behavior and have more concern about investing in pair bonding, forming stable, sensible and a good working connection with a partner.

Past research has shown that lower 2D:4D has also been associated with higher circulating testosterone levels (Neave et al. 2003) and also greater sensitivity to testosterone (Manning et al. 2003). Based on previous research lower 2D:4D could be associated also with many possible determinants of male physical attractiveness such as masculine facial features, characteristics of male voice or more muscular physique that highly preferred in attractiveness ratings (Dixson et al. 2003). It can be speculated that greater prenatal androgen exposure may organize the development of those traits that make men more sexually attractive because they indicate greater fertility and better physical condition. The possession of such traits would in turn be conducive to behavioral strategies that involve high levels of mating effort (Roney and Maestripieri 2004). Here we have shown that prenatal testosterone priming affects the ideas about love. Men with higher, more feminine $2 \mathrm{D}: 4 \mathrm{D}$ ratio, tend to compensate their lower display of courtship behavior and social dominance by practicing romantic or game playing love. However, future research will be necessary to determine the mechanisms whereby prenatal androgen 
exposure may be translated into certain behavior. This work showed no association between number of CAG triplets indicating sensitivity of androgen receptor with love styles in young population of men. We assume larger sample would be needed to prove this kind of relationship.

To conclude, this work points out that our romantic behavior can have a biological foundation. Concentrations of steroid hormone testosterone correlate with love style we adopt in social interactions. To our best knowledge this is the first work investigating how testosterone and its metabolism modulate the way individual practice love in romantic relationships. It points out the independent nature of behavior in relationships that should be considered social neuroendocrine research.

We are aware of several limitations of this work. Firstly, total testosterone was measure in plasma. Determining free and/or bioavailable testosterone would be more accurate assessment of biological activity. Secondly, the love style can change during the life and also during the relationship phases. The status of participants, durations and quality of their relationships has not been investigated. Romantic behavior can be highly affected by socio cultural environment, education, type of personality, cognitive control and many other external factors. Future studies should address questions about the family and social background of participants to differentiate here between moral rules, socialconventional rules and biological foundation of certain behavior. It is also important to consider other unmeasured variables that may contribute to the associations we observed. For instance, stable personality characteristics, such as extraversion, dominance, and pro-sociality, have been linked with endogenous testosterone levels (Alvergne et al. 2010). Moreover, it is also important to state that testosterone and its metabolism is definitely not the only biological force potentially organizing the brain and behavior. Other hormones of steroid metabolome certainly play its role and might be of interest. Future studies assessing the role of other interesting molecules namely dehydroepiandrosterone (DHEA) could shed more light into the effect of steroids on brain and behavior. The main complication of every work studying the effects of particular hormones on certain aspect of human behavior is the fact that specific hormone never acts alone. A possible interlink between hormonal milieu and sensitivity of behavior to many other external stimuli brings a lot of complexion into psycho-neuro-endocrine research.

\section{Conflict of Interest}

There is no conflict of interest.

\section{Acknowledgements}

This work was supported by grants VEGA 1/0052/15, Comenius University Science Part, EU structural funds, ITMS 26240220086.

\section{References}

ALVERGNE A, FAURIE C, RAYMOND M: Variation in testosterone levels and male reproductive effort: insight from a polygynous human population. Horm Behav 56: 491-497, 2009.

ALVERGNE A, JOKELA M, LUMMAA V: Personality and reproductive success in a high-fertility human population. Proc Natl Acad Sci U S A 107: 11745-11750, 2010.

ARCHER J: Testosterone and human aggression: an evaluation of the challenge hypothesis. Neurosci Biobehav Rev 30: 319-345, 2006.

BEATON AA, RUDLING N, KISSLING C, TAURINES R, THOME J: Digit ratio (2D:4D), salivary testosterone, and handedness. Laterality 16: 136-155, 2011.

BURNHAM TC, CHAPMAN JF, GRAY PB, MCINTYRE MH, LIPSON SF, ELLISON PT: Men in committed, romantic relationships have lower testosterone. Horm Behav 44: 119-122, 2003.

CHO W, CROSS SE: Taiwanese love styles and their association with self-esteem and relationship quality. Genet Soc Gen Psychol Monogr 121: 281-309, 1995.

DE BOER A, VAN BUEL EM, TER HORST GJ: Love is more than just a kiss: a neurobiological perspective on love and affection. Neuroscience 201: 114-124, 2012.

DIXSON AF, HALLIWELL G, EAST R, WIGNARAJAH P, ANDERSON MJ: Masculine somatotype and hirsuteness as determinants of sexual attractiveness to women. Arch Sex Behav 32: 29-39, 2003. 
EDELSTEIN RS, VAN ANDERS SM, CHOPIK WJ, GOLDEY WL, WARDECKER BM: Dyadic associations between testosterone and relationship quality in couples. Horm Behav 65: 401-407, 2014.

FARRELLY D, OWENS R, ELLIOTT H, WALDEN H, WETHERELL M: The effects of being in a "new relationship" on levels of testosterone in men. Evol Psychol 13: 250-261, 2015.

FRANCESCO F, CERVONE A: Neurobiology of love. Psychiatr Danub 26 (Suppl 1): 266-268, 2014.

GOMPEL N, PRUD'HOMME B: Behavioural neurobiology: Chemical love. Nature 461: 887-888, 2009.

GREENLAND KJ, BEILIN J, CASTRO J, VARGHESE PN, ZAJAC JD: Polymorphic CAG repeat length in the androgen receptor gene and association with neurodegeneration in a heterozygous female carrier of Kennedy's disease. J Neurol 251: 35-41, 2004.

HENDRICK C, HENDRICK SS, DICKE E: The love attitude scale: short form. J Soc Pers Relat 15: 147-159, 1998.

KUZAWA CW, GETTLER LT, MULLER MN, MCDADE TW, FERANIL AB: Fatherhood, pairbonding and testosterone in the Philippines. Horm Behav 56: 429-435, 2009.

LASSWELL TE, LASSWELL ME: I love you but I'm not in love with you. J Marital Fam Ther 2: 211-224, 1976.

LEE JA: Colours of love: an exploration of the ways of loving. New Press, Toronto, 1973.

LEE JA: Love styles. In: The Psychology of Love. BARNES MH, STERNBERG RJ (eds), Yale University Press, New Haven, 1988, pp 38-67.

MANNING JT, ROBINSON SJ: 2nd to 4th digit ratio and a universal mean for prenatal testosterone in homosexual men. Med Hypotheses 61: 303-306, 2003.

MANNING JT, CALLOW M, BUNDRED PE: Finger and toe ratios in humans and mice: implications for the aetiology of diseases influenced by HOX genes. Med Hypotheses 60: 340-343, 2003.

MARAZZITI D, CANALE D: Hormonal changes when falling in love. Psychoneuroendocrinology 29: 931-936, 2004.

MCINTYRE M, GANGESTAD SW, GRAY PB, CHAPMAN JF, BURNHAM TC, O'ROURKE MT, THORNHILL R: Romantic involvement often reduces men's testosterone levels--but not always: the moderating role of extrapair sexual interest. J Pers Soc Psychol 91: 642-651, 2006.

NEAVE N, LAING S, FINK B, MANNING JT: Second to fourth digit ratio, testosterone and perceived male dominance. Proc Biol Sci 270: 2167-2172, 2003.

PARK JH, WIELING MB, BUUNK AP, MASSAR K: Sex-specific relationship between digit ratio (2D:4D) and romantic jealousy. Pers Individ Dif 44: 1039-1045, 2008.

RONEY JR, MAESTRIPIERI D: Relative digit lengths predict men's behavior and attractiveness during social interactions with women. Hum Nat 15: 271-282, 2004.

SIMMONS ZL, RONEY JR: Variation in CAG repeat length of the androgen receptor gene predicts variables associated with intrasexual competitiveness in human males. Horm Behav 60: 306-312, 2011.

VAN ANDERS SM, WATSON NV: Testosterone levels in women and men who are single, in long-distance relationships, or same-city relationships. Horm Behav 51: 286-291, 2007.

WOROBEY J: Sex differences in associations of temperament with love-styles. Psychol Rep 89: 25-26, 2001.

ZAK PJ, KURZBAN R, AHMADI S, SWERDLOFF RS, PARK J, EFREMIDZE L, REDWINE K, MORGAN $\mathrm{K}$, MATZNER W: Testosterone administration decreases generosity in the ultimatum game. PloS One 4: e8330, 2009.

ZEKI S: The neurobiology of love. FEBS Lett 581: 2575-2579, 2007. 